\title{
Field Work in Accredited Library Schools
}

$\mathrm{E}^{\mathrm{n}}$ Ducation for librarianship poses problems that receive scant attention in our professional literature. In contrast to the many studies on all phases of primary, secondary, and higher education, there have been fewer than ten major studies of education for librarianship in the past twenty-five years. The authors of The Program of Instruction in Library Schools cite but seven references in their survey of the growth of professional training and note at the end of their introductory chapter that the instructional program in library schools is today far behind other advances in education for librarianship. They write:

The difficulties in this regard are concerned directly or indirectly with:

I. The training and educational qualifications of the instructors.

2. The fact that so much of the library school program is of an elementary nature.

3. The fact that there is no philosophy of librarianship to give point and depth to certain parts of the program. ${ }^{1}$

The third point suggests the need for investigating not only the general philosophy of librarianship but also the teaching philosophies in librarianship. The purpose of this paper is to examine the present status of field work in the programs of accredited library schools, in the belief that this specific question leads directly to basic questions of library educational philosophy and, ultimately, to the still more difficult question of a general philosophy for librarianship.

1 Metcalf, Keyes D., Russell, John D., and Osborn, Andrew D, The Program of Instruction in Library p. 7 .

\section{I}

The philosophy of library education with respect to the value of field work has been similar to the swing of a pendulum. The early library schools emphasized the practical; present schools tend to emphasize the theoretical sides of librarianship; and there are indications that a re-evaluation of both philosophies of librarianship are in store for the near future. A brief review of the history of field work theory illustrates these changing assumptions.

Melvil Dewey, in the first catalog of the School of Library Economy of Columbia College, states the apprenticeship method with which American library schools began. The aim of Mr. Dewey's curriculum was entirely practical: to give the best obtainable advice with specific suggestions for the solution of the questions that arise from the time a decision is made that a library is desirable until it is placed in perfect working order. ${ }^{2}$

The Williamson report, Training for Library Service, stimulated library educational philosophy to move in the direction of more emphasis upon the professional or theoretical aspects of librarianship. After an examination of field work requirements in the library schools of the early twenties, Mr. Williamson concluded that it should be looked upon as that phase of formal instruction carried on by purposeful observation supplementing classroom instruction. $\mathrm{He}$

2 School of Library Economy of Columbia College, 1887-89; Documents for a History. New York, Scliool of Library Service, Columbia University, 1937, p. 90. 
recommended decreased emphasis but not the elimination of field work from the library school curriculum. In his opinion it was still one important method of instruction. $^{3}$

Thirteen years later the pendulum had swung still farther away from acceptance of the field work method. Ernest J. Reece, in The Curriculum in Library Schools, recommends that field work supplement the library school curriculum through summer assignments or postschool internships. $\mathrm{He}$ places special emphasis upon the separation of field work from the curriculum. ${ }^{4}$ It is a short step from this position to the complete elimination of all field work requirements in a few accredited library schools at the present time.

The need for a re-evaluation of library field work is evident in the recent study by the authors of The Program of Instruction in Library Schools. They recommend more careful planning, supervision, and reporting of field work experience and advocate the search for new devices such as clinics and motion pictures for presenting the practical aspects of librarianship.

\section{II}

If we turn from library educational theory to contemporary library school practice, what has been the effect of theory upon practice with regard to the status of field work? In an attempt to secure the necessary data for an answer to this question, a questionnaire was sent in 1944 to the thirtyfour library schools accredited by the American Library Association through its Board of Education for Librarianship. Thirtytwo schools replied. This high percentage of replies is testimony to the interest of the

${ }^{3}$ Williamson, C. C. Training for Library Service; $A$ Report Prepared for the Carnegie Corporation of New York. New York, Iq23, p. I39-40.

4 Reece, Ernest J. The Curriculum in Library Schools. New York City, Columbia University Press, r936, p. I 29-30. faculties of our library schools in this subject.

Twenty-eight schools indicated that some form of field work is required of at least some students. Of these schools, two reported that field work is required only of future school librarians. Two others indicated that longer field work periods are required of those preparing for school librarianship than for other students. In one case, special field work in addition to the regular period is required for those preparing for special library work. Of the twenty-eight, two indicated that field work is not required for students entering with substantial experience in library work.

Twelve schools require blocked practice periods only ; three indicated that field work is done in connection with classes; ten reported that they require both blocked field work and periods of practice work scheduled with classes. Two have pre-matriculation periods of practice, and one did not answer this question.

The most common length of time for the blocked practice period is two weeks (8o hours). Sixteen schools use the two-week period; the others range from one week to one month.

The type of library in which the student practices depends upon a number of factors. Five schools specializing in the training of school librarians or who require practice only of future school librarians limit field work almost invariably to school libraries. Twenty schools indicated that public, school, college, university, or special libraries are used. Two said that public libraries are generally chosen, and one school uses both public and school libraries for all students.

In choosing libraries for field work, knowledge by the library school of the libraries is the determining factor in fifteen schools; students' interest in a specific li- 
brary, in four schools; and both factors, in nine others. Among the factors considered by library school directors in the selection of supervising libraries are the interest and training of the supervising librarian, the time that the librarian has to give to supervision, the locality, and the nature of the library program.

The supervision of the field work of twenty-three schools is done entirely by the cooperating librarian and his staff. In only two schools is the work supervised entirely by instructors from the library school. In three schools the library school staff aids the cooperating librarian in supervision. In most cases a rating scale is filled out by the cooperating librarian. These rating scales usually contain a series of questions about traits, technical efficiency, special aptitudes, and ask for general estimates and comments.

Follow-up work on deficiencies revealed by the field work is handled by a conference with the student in nineteen schools; with stress in subsequent classwork, in two schools; by a combination of individual classwork and conference, in four schools; by faculty discussion of ratings, in one school; and by oral reports and discussion of ratings, in one school. One school has only a pre-matriculation practice period and tries to correct personality defects during the year of residence. In only two schools is any attempt made to secure any written reaction from the student.

Twenty-six schools reported that the period is valuable. Approval is qualified in two cases to apply only to school librarians. Two schools with practice periods report that it is not especially valuable. Of the four reporting no use of a practice period, one indicated that it has an observation period and that the discussion of field work will be reopened when the curriculum is revised; one mentioned special field work projects from time to time but no regular period. Only two are firmly convinced that the period has no value.

To the question as to whether or not the field work program should be modified, thirteen replied in the affirmative and thirteen in the negative. In five schools the matter is now under consideration. Suggestions for modification included more practice (nine schools), more practice if library course were two years in length (three schools), more professional and less routine field work (three schools), and the addition of funds for library school faculty visits to supervising libraries (one school).

The last question on which reports were made was concerned with the use of practice situations involved in teaching. specific courses; for example, the assignment of reference students to the college or university reference desk one or more hours per week. Ten schools reported that they use this type of teaching device in one or more of the following courses: administration, reference, book selection, circulation, methods, cataloging, and hospital libraries.

\section{III}

It is clear from the survey of current field work practices that Mr. Williamson's recommendations for decreased emphasis upon field work have been followed by the majority of library schools. A period of field work from four to twelve weeks in length was universally required by the library schools in 1920-2 I. By 1944, four schools had dropped the requirement entirely, two others demanded it only for prospective school librarians, and two others had flexible arrangements qualified by the amount of library experience each student brings to library school. Furthermore, the period devoted to field work has been cut to one to four weeks.

A large majority of the representatives of accredited schools, however, still consider 
that this experience is invaluable. The reasons given are quite different from those cited by library school directors in the Williamson report. Classification of about twenty-five statements of the reasons for field work reveal four main categories:

I. Field work develops an understanding of what goes on in a library, allows for selfevaluation and the testing of theories, shows the unity of the library school course, gives the "feel" of library service, provides contact with active libraries and a sense of concreteness. Statements such as these occurred in twenty-four questionnaires. The common element in these opinions is the conviction that field work is a teaching device which clinches classroom points, reveals interrelationship of courses, and makes the textbooks come alive.

2. Field work develops student confidence and poise and increases professional enthusiasm. This is the gist of the replies in twentythree questionnaires.

3. Many library school graduates, especially school librarians, go into "one-man" situations. They may anticipate little or no expert supervision and must have a trial period under supervision so that they will not be entirely unacquainted with the variety of practical problems for which they will be responsible. This was mentioned only twice, but it deserves careful attention.

4. Three schools mentioned the value of the field work for placement.

The placement consideration is the only factor which is identical with the reasons given by the library school directors of I920-2I for the field work requirement. Library school directors of 1944, unlike those of 1920 , mention only once or twice the fact that routine skills may be learned. They stress the value of field work for the learning process that comes from comparison of theory with practice and for the integration of library functions. While the deans in 1920 decided that field work is needed to reveal student capacity for library work, the directors in 1944 stress the importance of the period for the development of the professional point of view. In general, present library school theory is based upon Mr. Williamson's idea that field work should be an instructional period pointing up the application and integration of theories rather than a period for the learning of routine skills.

How does this theory work in practice? Turning to the reasons given by the four schools which do not require field work and to the one school which, although disapproving in principle, is forced by state requirements to schedule this period for school librarians, we find the following objections:

I. Cadets are often exploited by assignment to routine work which the regular library staff has saved for them.

2. There are difficulties and unjustifiable expense involved in finding qualified libraries with supervision which has educational value and staffs organized upon a sound professional-and-clerical basis.

3. The problem method in specific courses is a more economical way of securing the same results.

4. There are many difficulties involved in the cooperation of librarians and library schools in this matter. Most librafians are not interested in teaching.

Many of the schools which do use field work assignments list these same criticisms, especially the danger of exploitation, but feel that the advantages outweigh the disadvantages. Several point out that their field work is directed more toward observation than toward active library work. One school indicates the need for a larger budget to permit supervision of cadets while in their field positions. Several report that more attention should be paid to follow-up procedures.

Only one of the four chief objections to field work is theoretical in nature. This is the position that the problems method in specific courses gives the same result with more economy than field work. All the other objections are practical. They all follow the form: "If the situation were 
different, field work might be useful." The implication is that the cost in time, money, and effort to secure conditions under which field work would be ideal are exorbitant.

\section{IV}

If the library field work period has possibilities as a teaching device and as an instrument to hasten the growth of professionalism, can anything be done to eliminate the practical difficulties mentioned by library school directors? The Department of Library Education at State Teachers College, Geneseo, N.Y., has been experimenting with field work practices over a long period and believes it can offer evidence for the following propositions:

I. Where a library school prepares librarians for one or two types of libraries, field work can be administered successfully with a very small staff. Under these conditions no insuperable difficulties have been met with regard to selection of excellent cadet centers, elimination of exploitation of students, supervision by the library school staff, and careful follow-up work for individual deficiencies.

2. When properly integrated with theoretical courses, the field work period proves to be an economical device for teaching students to apply theory.

3. Field work pays high dividends in developing professional attitudes among students.

4. The field work period is an effective instrument for discovering necessary curricular adjustments, both in the library program and in the academic courses pursued by the students.

5. The field work period exerts a beneficial professional effect upon the practicing librarians supervising the cadets.

The Department of Library Education at Geneseo trains librarians for the public schools of the State of New York. The thirty-six hours of the library curriculum are distributed throughout the four years, with most of the courses falling in the junior and senior years.

The field work period at Geneseo comes in the middle of the second semester of the junior year, following a period of practice teaching during which each student teacher is observed carefully to see how well he applies his knowledge of libraries in an actual classroom situation. Before students go to their field work centers, they are given topical outlines which are designed to direct their observation. These topics are discussed and students are required to submit papers summarizing and evaluating their field experience in terms of the topics outlined. Two days are devoted to intensive preparation for the six-week field work period.

Supervising librarians are furnished with a twenty-two-point rating scale and are asked to check a list of library, school, and community activities in which the cadet has had an opportunity to participate. In addition, a library school instructor visits each cadet at least once while he is in residence in the field. These visits are usually made not later than the third week in order that the instructor can be helpful if problems of personality or procedure have arisen.

Field work centers are chosen carefully upon the basis of a knowledge of the school and the librarian. When there are indications that the cadet is kept busy with routine or even with a limited group of professional activities, the objectives for requiring practice in a wide variety of professional fields are explained to the supervising librarian at the time of the visit. Field work centers are scrutinized each year and eliminated when unsatisfactory for the set purposes. In addition, conferences with supervising librarians have been held at the college to secure the joint contributions of librarians in the field for the improvement of courses and the field work program and to explain the objectives. The last conference of this type resulted in an improved rating scale.

When the cadets return to the campus, 
there are two types of follow-up procedure. First, the instructor for school library service and the head of the department read the field work papers submitted and check the rating scales and the lists of activities in which the cadet has participated. Each student is then interviewed and questioned closely about which procedures or situations were easy and which were difficult. On the basis of the paper, the rating scales, the visits of instructors to field work centers, and the student interview, prescriptions are made for the senior year. For example, eight or ten students are reported each year to the speech department for special training to eliminate speech defects, to give more experience and confidence in making book talks, and to improve efficiency in all public relations work involving speech.

The course in school library administration, to which the full time of the juniors is devoted during the last four weeks of the semester, provides the second follow-up procedure for the field work period. This course is built around standard readings and problems in library administration and the experience which each student brings from his field work. Discussion of school library circulation systems, for example, draws upon the various systems in use in field work centers as well as upon textbooks. Discussion of all problems is enlivened with at least the beginnings of practical experience.

The careful integration of field work with other library and academic courses can be one of the strongest teaching and professional training devices in the curriculum. Many students who are only average or below average have suddenly found themselves during these periods. Observation of students applying library theories may result in suggestions for the improvement of courses. For example, correlated courses in the education department have been strengthened through suggestions from students who have analyzed their difficulties. Many supervisors have also indicated that they have obtained new ideas from cadets.

\section{V}

Does the foregoing discussion cast any light upon the basic questions of library educational philosophy or of a philosophy of librarianship in general? If field work problems are typical of other library school teaching enigmas, we are justified in looking for more practical than theoretical difficulties in our profession. Perhaps the essence of the teaching philosophy for which we are searching is found in discovery of ways to fit means to ends rather than in the discovery of the ends themselves.

The first step toward a philosophy of library education may be made through a careful study of the existing specific techniques used in the teaching of library courses. The Program of Instruction in Library Schools considers library school instructional problems in general and is the most helpful recent publication in this field. There is need, however, for a survey of specific techniques in library education. The listing, analysis, evaluation, and publication of all types of assignments, projects, problems, and devices used in the teaching of subjects in the field of librarianship should prove to be a most effective way to begin the improvement and reorientation of library school instructional programs. This publication should stimulate all library schools to evaluate and perfect their teaching methods and would present the raw material for this evaluation-the collective teaching experience of all schools.

A second step toward a working philosophy of librarianship might come with the formation of an association embracing all library school faculties in its membership. The American Association of Library 
Schools limits its membership to faculties of accredited library schools. This in effect means that those schools which might conceivably benefit most by association are excluded from the advantages of an effective means for the interchange of professional library teaching ideas. This association of all library schools would be similar to the American Library Association for general librarianship ; it would welcome all interested in library educational problems.

With detailed knowledge of present teaching techniques in use in all library schools and with an association admitting the entire professional library teaching personnel, we would have the lever and the wheel necessary for an examination of what teaching in the field of librarianship should be. At this point a third step toward our

\section{A Theory of Subject Headings}

\section{(Continued from page 248)}

ings of Bliss $^{9}$ or Kelley ${ }^{10}$ or of practical rules proposed by Van Hoesen. ${ }^{11}$ But several problems needing further investigation should be noted. At first glance, one might expect that an increased number of headings would mean a much greater number of cross references, but there is some reason for thinking that fuller use of correct and up-to-date headings would mean fewer see and see also references; the relative scarcity of both in such a detailed and specialized index as that of Psychological Abstracts is interesting in this connection. The relation between the theory suggested above and the classified catalog needs discussion. My own experience, as well as that of Helen Starr, ${ }^{12}$ is

9 Bliss. H. E. Organization of Knowledge in Libraries and the Subject Approach to Books. New York City, Wilson, I 939

10 Kelley. G. O. Classification of Books: an Inquiry into Its Usefulness to the Reader. New York City, Wilson, I 937

${ }_{11}$ Van Hoesen, op. cit.

12 Starr, H. K. "Subject Headings in a Changing World." Library Journal 59:2'05, Mar. I, I 934. professional philosophy may be taken by inviting practicing librarians and the users of their libraries to contribute to the understanding of the type of library personnel which should be produced.

These three steps are in themselves an enormous order, and the goal lies still further. This goal of librarianship is well known. Librarianship aims to mate readers and ideas found in printed and nonprinted materials in any way that will be fruitful. What is not well known is that it is much easier to see where you want to go than to provide and utilize the means for getting there. The crucial problems in a philosophy of librarianship are not scientific or philosophical, but engineering problems concerned with time, money, and personnel with ingenuity for fitting means to ends.

that the use of more specific headings reduces the average number of subject entries per title (actually, since a cataloger who is also a subject matter specialist can often omit less essential added or title entries, savings are even greater); whether this would hold true for all fields is a problem to be investigated. Catalogers who are also subject specialists would undoubtedly discover legitimate needs which our catalogs do not now meet $;^{13}$ on the other hand, they could probably withdraw large numbers of cards relating to fields where adequate bibliographies are available. The approach to subject headings suggested here implies changes in the organization of cataloging work and in library school curricula. But these problems are better left for future discussion.

\footnotetext{
${ }^{13} \mathrm{Cf}$. McMurtrie, D. C. "Locating the Printed Source Material for United States History." Mississippi Valley Historical Review 3I:369-406, December I 944 .
} 